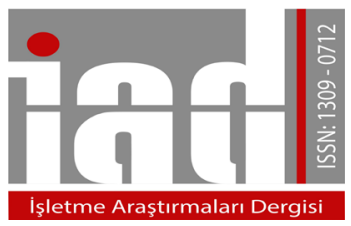

\author{
İşletme Araştırmaları Dergisi \\ Journal of Business Research-Turk \\ 10/4 (2018) 575-599
}

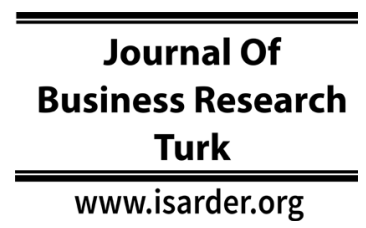

Araștırma Makalesi

\title{
Akıllı Telefon Pazarında Marka İmajının Müşteri Sadakati Üzerindeki Etkisinde Müşteri Memnuniyetinin Aracılık Rolü \\ The Mediating Role of Customer Satisfaction in The Impact of Brand Image on Customer Loyalty in The Smartphone Market
}

\author{
Gamze ULUDAĞ \\ Düzce Üniversitesi \\ Sosyal Bilimler Enstitüsü \\ İşletme ABD Doktora Öğrencisi \\ Düzce, Türkiye \\ orcid.org/0000-0002-6504-1079 \\ gamzeuludag1993@,hotmail.com
}

\author{
Emel FAIZ \\ Düzce Üniversitesi \\ İşletme Fakültesi \\ Uluslararası İlişkiler Bölümü \\ Düzce, Türkiye \\ orcid.org/0000-0002-1911-7706 \\ emelgokmenoglu@duzce.edu.tr
}

\author{
Kahraman ÇATI \\ İnönü Üniversitesi \\ İktisadi ve İdari Bilimler Fakültesi \\ İşletme Bölümü \\ Malatya, Türkiye \\ orcid.org/0000-0002-7440-5436 \\ kahraman.cati@,inonu.edu.tr
}

\section{Özet}

$\mathrm{Bu}$ araştırmanın temel amacı, akıllı telefon pazarında marka imajının müşteri sadakati üzerindeki etkisinde müşteri memnuniyetinin aracılık rolünün olup olmadığını belirlemektir. Araştırmanın evrenini Düzce'de ikamet eden 17 yaş ve üzeri akıllı telefon kullanan tüketici grubu oluşturmaktadır. Bu çerçevede kolayda örnekleme yöntemi kullanılarak 385 akıllı telefon kullanıcısından çevrimiçi anket tekniğiyle elde edilen veriler analize tabi tutulmuştur. Araştırma kapsamında marka imajının müşteri sadakati üzerindeki etkisinde müşteri memnuniyetinin aracılık rolünü belirlemek amacıyla Baron ve Kenny' nin (1986) dört aşamadan oluşan Nedensel Adım Yaklaşımı kullanılmıştır. Aracılık modelinin istatistiksel olarak anlamlılığını belirlemek için Sobel Testi kullanılmış ve sonuç istatiksel olarak anlamlı çıkmıştır. Çalışma sonucunda, marka imajının müşteri memnuniyeti ile müşteri sadakati üzerinde etkisi olduğu ve aynı zamanda müşteri memnuniyetinin de müşteri sadakatini doğrudan etkilediği tespit edilmiştir. Çalışmanın temel amacı olan, marka imajının müşteri sadakati üzerindeki etkisinde müşteri memnuniyetinin 'kısmi aracı' değişken olduğu sonucuna ulaşılmıştır.

Anahtar Kelimeler: Marka İmajı, Müşteri Memnuniyeti, Müşteri Sadakati, Aracı Etki

Gönderme Tarihi 13 Ekim 2018; Revizyon Tarihi 30 Kasım 2018; Kabul Tarihi 2

Aralık 2018

\section{Önerilen Atıf/ Suggested Citation:}

Uludağ, G., Faiz, E., Çatı, K. (2018). Akıllı Telefon Pazarında Marka İmajının Müşteri Sadakati Üzerindeki Etkisinde Müşteri Memnuniyetinin Aracılık Rolü, İşletme Araştırmaları Dergisi, 10 (4), 575-599. 


\begin{abstract}
The main purpose of this research is determine whether or not the mediating role of customer satisfaction in the effect of brand image on customer loyalty in smartphone market. The researchers' universe constitutes a consumer group that uses smartphones over 17 years of age and lives in Düzce. In this frame, using convenience sampling method the data obtained through online questionnaire from 385 smartphone users were analyzed. Within the scope of research, the four-stepped The Causal Inference Approach of Baron and Kenny (1986) was used to determine the mediating role of customer satisfaction on brand image's effect on customer loyalty. The Sobel Test was used to determine the statistical significance of the mediating model and the result was statistically significant. As a result of the study, it was determined that not only brand image has a direct effect on the customer loyalty and customer satisfaction but also customer satisfaction effects customer loyalty directly. The main aim of this study is brand image's effect on customer loyalty resulted in customer satisfaction's influence on customer loyalty is 'partial mediator' variable.
\end{abstract}

Keywords: Brand Image, Customer Satisfaction, Customer Loyalty, Mediating Effect

Received 13 October 2018; Received in revised from 30 November 2018; Accepted 2 December 2018

\title{
1. Giriş
}

Günümüz yoğun rekabet ortamında işletmeler pazar paylarını koruyabilmek ve tüketicilerin kendilerine bağlanmalarını sağlayabilmek için müşteri sadakati üzerine stratejiler geliştirme çabası içerisine girmişlerdir. Geliştirilen bu stratejiler arasında en önemli araçlardan biri olarak kullanılan müşteri memnuniyeti, tek başına müşteri sadakati üzerinde güçlü bir etkiye sahip olamamaktadır. Bu nedenle işletmelerin rekabet ortamında tüketicilerin beklentilerini karşılamanın yanında, rakiplerinden farklılaşmasını sağlayan araçlara yönelmesi gerekmektedir. $\mathrm{Bu}$ farklılaşmanın sağlanması aşamasında marka ve yeni ürün geliştirme ilişkisi işletmeleri bir adım öne taşıyarak rekabet ortamında avantaj elde etmesini sağlamaktadır (Uç ve Tolon, 2016: 46). Ancak farklılaşmanın en önemli araçlarından birisi olarak kullanılan marka kavramı, her zaman müşteri tercihini ve sadakatini oluşturmaya yetmemektedir. Markanın müşteri dünyasında olumlu bir imajı da olmalıdır. Olumlu bir marka imajı, tüketiciye ulaşmanın en etkili yoludur (Yetkil, 2017, s. 46). Marka imaj1 sayesinde, tüketiciler kendi beklentilerini karş1layabilecek, memnuniyet düzeylerini artırabilecek ve kendilerini mutlu hissedebilecekleri işletmeleri tercih etmektedir (Erciş, Geçikli ve Çat, 2016, s. 47). Memnun edilmiş tüketiciler ise zamanla işletme için tüketici konumundan sadık birer müşteri konumuna gelmektedir. Kısacası, imaj1 yüksek markalar tüketicilerin beklentilerini karşıladığında onların işletmeden memnun bir şekilde ayrılmasını sağlamakta, memnun olarak ayrılan tüketiciler daha sonra bu işletmenin sadık birer müşterisi olmaktadır. Sonuç olarak marka imajı ve müşteri sadakati arasında müşteri memnuniyetinin bir köprü görevi üstlendiği görülmektedir.

Marka imaj1, müşteri memnuniyeti ve müşteri sadakati değişkenleri ile ilgili literatür incelendiğinde birçok çalışmada marka imajının müşteri memnuniyeti üzerinden müşteri sadakati oluşturduğu sonucuna ulaşılmaktadır. Bu çalışmalar değerlendirildiğinde, Lai, Griffin ve Babin (2009) mobil iletişim sektörü, Sondoh Jr ve 
Diğ. (2007) kozmetik sektörü, Andreani, Taniaji ve Puspitasari (2012) McDonald's, Sulibhavi ve Shivashankark (2017a) özel etiket markaları gibi farklı sektör ve farklı hedef kitlesi üzerinde gerçekleştirdikleri araştırmalarında marka imajının müşteri sadakati üzerindeki etkisinde müşteri memnuniyetinin aracılık rolünü üstlendiği sonucuna ulaşmışlardır.

Bu çalışmada akıllı telefon sektörü hedef kitle olarak belirlenmiştir. Çalışmada hedef kitle belirlenirken, akıllı telefon kullanım oranının gittikçe artmasına, akıllı telefona olan talebin hızla büyümesine ve müşteri ile akıllı telefon arasında bir bağlılık oluşmasına karşın literatürde konu ile ilgili çalışmaya rastlanılmaması etkili olmuştur. Kullanım oranı her geçen gün artan akıllı telefon sektörü birçok işletmenin dikkatini çekerek bu sektöre dâhil olmalarına neden olmuştur. Müşteriyi elde tutmak ve tercih edilen marka olmak için her gün yeni markaların ve modellerin rekabete katıldığ gözlemlenmektedir.

Akı1lı telefon üreten ve pazarlayan markaların sayısı ve her markanın pazara sunduğu telefon çeşitliliğinin artması sonucu müşterilerin markalara ne kadar sadakat gösterdiği konusunu çalışmayı gerektirmektedir. Müşterinin tercih edebileceği çok sayıda alternatifin olduğu bir ortamda müşteri sadakatini etkileyecek unsurların belirlenmesi işletmelere önemli faydalar sağlayacaktır. Bu bağlamda, marka imajının müşterileri sadakati üzerindeki etki derecesinin belirlenmesi, hem literatüre katk1 sağlayacak hem de müşteri sadakati oluşturmak isteyen işletmelere yol gösterici olacaktır.

\section{Kuramsal Çerçeve}

\subsection{Marka İmajı}

Günümüzde markaların rekabette üstünlük sağlaması için sadece temel fonksiyonlarını yerine getirmesi yeterli olmamaktadır. Temel fonksiyonların yanı sıra markaların rakip markalardan farklı olduklarına, müşterileri ikna edecek başka fonksiyonlara ya da mesajlara ihtiyacı vardır. Bunlardan birisi de marka imajıdır. Meenaghan (1995, s. 24) marka imajını, "belirli bir marka hakkında sahip olunan inançlar dizisi" veya "anlamlı şekilde organize olmuş bir dizi çağrışımlar grubu” olarak ifade etmektedir. Diğer bir ifadeyle marka imajı, tüketicilerin markayı nasıl algıladığ ile ilgili bir kavramdır (Can, 2007, s. 231). Tüketiciler zihinlerinde marka imajını oluşturabilmek için marka ya da işletmelerle ilişki kurmaktadır. Her tüketici belli bir markayla farklı ilişkiler kurduğundan dolayı, markanın çağrışımları da tüketiciden tüketiciye değişkenlik göstermektedir (Hung, 2008, s. 239). İşletmeler bu farklılığ düşünerek, tüketici zihninde markasının olumlu bir imaja sahip olmasını sağlamak için etkili pazarlama stratejileri geliştirmesi gerekmektedir. Geliştirilen stratejiler sonucunda tüketiciye nüfuz eden ve zihninde olumlu olarak kodlanan marka imajı, tüketicinin satın alma ve karar verme sürecinde önemli rol oynamaktadır (Ergülşen, 2014, s. 102).

Tüketicilerin marka hakkındaki geçmiş deneyiminin algılanma şekli olan marka imaj1, eğer olumlu olursa, tüketici zihninde güçlü bir konum oluşturulabilir, marka rekabet ortamında diğer markalara karşı güçlenebilir ve dolayısıyla markanın pazar performansını artırılabilir. Ancak marka imajını oluşturan şey, tüketicilerin deneyimleri sonucu oluşan algılar olduğundan ötürü algılar değiştikçe imaj da değişecektir. İşletmelerin marka imajı yönetiminde tüketici algılarını sürekli olarak ölçümlemesi marka imajının olumlu kalmasına katkı sağlayacaktır. 


\subsection{Müşteri Memnuniyeti}

Fornell (1992, s. 12) müşteri memnuniyetini, bir müşterinin bir mal veya hizmeti satın alma öncesi beklentisi ile satın alma sonrası oluşan performansının genel değerlendirmesi sonucunda elde ettiği yeterlilik seviyesi olarak ifade etmektedir. İşletmelerin müşterilerin beklentisini karşılaması olumlu duyguların oluşmasına ve sonucunda işletmeden memnun bir şekilde ayrılmasına neden olmaktadır (Yalçın ve Koçak, 2009, s. 20). Memnun olarak işletmeden ayrılan müşteriler, memnun olmayan müşterilere göre daha yüksek seviyede mal ve hizmet satın alma eğiliminde olmaktadır. İşletmeler müşterilerini memnun ederek sadece onların daha fazla mal ve hizmet satın almasını sağlamayı değil onlar ile uzun süreli ilişkiler kurmayı arzu ederler. Memnun olan müşteri işletmeye sadık birer müşteri olarak geri dönecektir. Literatürde birçok çalışma incelendiğinde, müşteri memnuniyetinin müşteri sadakatini oluşturmada en önemli değişkenler arasında yer aldığı belirlenmiştir (Anderson, Fornell ve Rust, 1997, s. 131; Bruhn ve Grund, 2000, s. 1017; Ibanez, Hartmann, ve Calvo, 2006, s. 635; Kim, Park, ve Jeong, 2004, ss. 148- 149; NQRC, 1995, s. 5).

\subsection{Müşteri Sadakati}

Dick ve Basu (1994, s. 101) müşteri sadakatini, bir işletmenin mal veya hizmetlerine karşı olumlu bir tutum ve tekrarlı satın alma arasındaki uzun vadeli ilişkinin gücü olarak ifade etmektedirler. Sadık müşterilere sahip olan işletmeler rekabet ortamında rakip işletmelerin sunduğu tüm tekliflere direnerek yine aynı işletmeden tekrarlı alışveriş gerçekleştirmekte ve işletmenin uyguladığı tüm fiyat politikalarına razı olmaktadır. İşletmeyi diğer tüketicilere tavsiye ederek hem ücretsiz reklamını gerçekleştirmekte hem de yeni müşteriler kazandırarak maliyetlerini en aza indirgenmesini sağlamaktadır (Tabaku ve Çerri, 2015, s. 226). Aynı zamanda sadık müşteriler devamlı olarak işletmeden satın alım gerçekleştirdiklerinden dolayı istikrarlı olmayan müşterilerden kaynaklanan satış ve karlılıktaki iniş çıkışları ortadan kaldırarak işletmenin pazar payını korumasını ve istikrarlı olmasını sağlamaktadır. Bu noktada, müşteri sadakati işletmelerin rekabet ortamında üstünlük elde etmesini sağlayan önemli bir stratejik araçtır (Değermen, 2004, s. 95).

\section{Yöntem}

\subsection{Araştırma Modeli ve Hipotezleri}

Araştırmanın amacı ve kapsamı gereği nicel araştırma desenlerinden biri olan nedensel tarama araştırması kullanılmıştır. Bu kapsamda, araştırma konusu olan marka imajının müşteri sadakati üzerindeki etkisinde müşteri memnuniyetinin aracılık rolünü belirlemek için nedensel karşılaştırmanın yapıldığı araştırma modeli Şekil 1'de gösterilmektedir. 


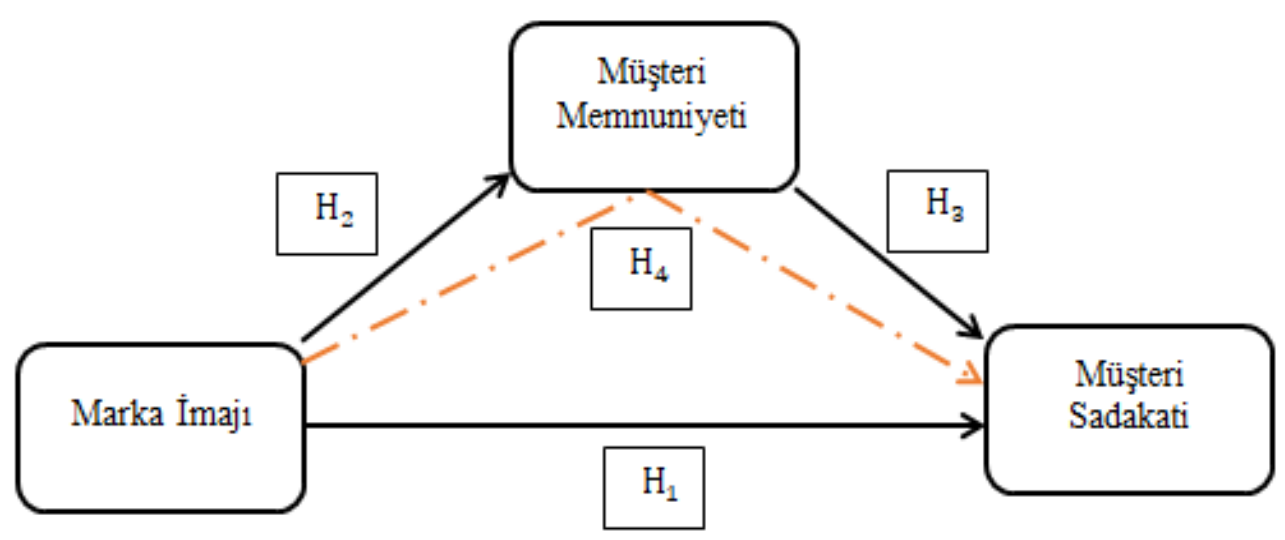

\section{Şekil 1: Araştırma Modeli}

Araştırma da bu kısım oluşturulurken literatürde yer alan çalışmaların sonuçlarından hareketle hem değişkenler arasındaki ilişkiler hem de müşteri memnuniyetinin aracılık etkisini dikkate alarak model çizilmiş ve hipotezler oluşturulmuştur.

$\mathrm{H}_{1}$ : Marka imajının müşteri sadakati üzerinde pozitif yönde bir etkisi vardır.

İşletmeler tarafından gerçekleştirilen pazarlama iletişimi çalışmaları sayesinde oluşturulan olumlu marka imajı, müşterilerde ilk olarak satın alma niyeti yaratmaktadır. Markaların güçlü ve olumlu bir imaj geliştirmesi, ayrıca müşterinin bir üründen algılayacağı riski de azaltmaktadır. Müşterilerin bir üründen algılayacağı riskin az olması, güven duygusu oluşturmakta ve bu durum tekrarlı satın alımları da beraberinde getirerek müşterilerde sadakatin oluşmasını sağlamaktadır (Stan, Caemmerer ve CattanJallet, 2013, s. 1544; Tabaku ve Çerri, 2015, s. 225). Bu konuyla ilgili literatür incelendiğinde, marka imajının müşteri sadakatini olumlu yönde etkilediği sonucuna ulaşılmıştır (Eren ve Eker, 2012, s. 464; Faullant, Matzler ve Füller, 2008, s. 173; Genoveva, 2015, s. 505; Hung, 2008, s. 241; Hussain, 2016, s. 247; Sulibhavi ve Shivashankar, 2017a, s. 46; Sulibhavi ve Shivashankar, 2017b, s. 3; Yetkil, 2017, s. 81). vardir.

$\mathrm{H}_{2:}$ Marka imajının müşteri memnuniyeti üzerinde pozitif yönde bir etkisi

Andreassen ve Lindestad'a (1998, s. 11) göre, iletişim ve deneyim yoluyla olumlu bir marka imaj1 oluşturulabilmektedir. Olumlu bir şekilde algılanan marka imajı, hem markanın karşıladığı ihtiyaçların müşteriler tarafından daha iyi anlaşılmasını sağlamakta hem de müşterilerin markayı rakiplerinden ayırarak müşteri memnuniyetinin sağlanmasında önemli bir rol oynamaktadır (Eren ve Eker, 2012, s. 456). Bir diğer ifadeyle, işletmeler tarafından olumlu bir şekilde yansıtılan marka imajı, müşterilerin beklentilerini karşılamayı ve onların işletmeden memnun ayrılmalarını sağlamaktadır (Sulibhavi ve Shivashankark, 2017a, s. 44). Bu konuyla ilgili literatür incelendiğinde, marka imajının müşteri memnuniyetini olumlu yönde etkilediği sonucuna ulaşılmıştır (Eren ve Eker, 2012, s. 464; Sulibhavi ve Shivashankar, 2017a, s. 47). 

vardir.

$\mathrm{H}_{3 \text { : }} \quad$ Müşteri memnuniyetinin müşteri sadakati üzerinde pozitif yönde bir etkisi

Müşteri sadakati, müşterinin mevcut bir işletmeden devamlı veya artan bir şekilde alış veriş yapma davranışı ve bu işletmeyi diğer kişilere önerme eğilimleri ile ölçülmektedir. İşletme ile müşteri arasında kurulan bu uzun vadeli ilişkinin temel itici gücü müşteri memnuniyeti olarak görülmektedir (Yang ve Peterson, 2004, s. 804). Bu uzun vadeli ilişkide memnun edilmiş müşteriler memnun edilmeyen müşterilere göre daha fazla mal ve hizmet satın alma eğilimindedir. Memnuniyetin sadakat üzerindeki olumlu etkileri arasında, müşterinin bir mal veya hizmeti geri satın alma niyeti, olumlu ağızdan ağza iletişim yoluyla diğer kişilere tavsiye etmesi sonucu işletmeye yeni müşteriler kazandırması ve bu sayede işletmenin itibarının artmasını sağlaması yer almaktadir (Anderson, Fornell ve Rust, R. T. 1997, s. 131; Bruhn ve Grund, 2000, s. 1017; Faullant, Matzler ve Füller, 2008, s. 164; Ibanez, Hartmann, ve Calvo, 2006, s. 635; Kim, Park ve Jeong, 2004, s. 148-149; Liat, Mansori ve Huei, 2014, s. 318; NQRC, 1995, s. 5). Literatürde var olan araştırmalar incelendiğinde müşteri memnuniyeti, müşteri sadakatinin oluşmasında temel belirleyici olduğu sonucuna ulaşılmaktadır (Faullant, Matzler ve Füller, 2008, s. 164). Bu noktadan hareketle, birçok araştırmada müşteri memnuniyetinin müşteri sadakatini olumlu yönde etkilediği sonucuna ulaşılmıştır (Andreani, Taniaji ve Puspitasari, 2012, s. 69; Chen ve Cheng, 2012, s. 814; Deng ve Diğ., 2010, s. 295; Faullant, Matzler ve Füller, 2008, s. 164; Hu, Kandampully ve Juwaheer, 2009, s. 115; Kim, Park ve Jeong, 2004, s. 154; Lin ve Wang, 2006, s. 276; Lai, Griffin ve Babin, 2009, s. 984; Liat, Mansori ve Huei, 2014, s. 320; Sondoh Jr ve Diğ., 2007, s. 96; Tu, Wang ve Chang, 2012, s. 30; Stan, Caemmerer ve Cattan-Jallet, 2013, s. 1543; Sulibhavi ve Shivashankark, 2017a, s. 48; Tabaku ve Çerri, 2015, s. 229; Yang ve Peterson, 2004, s. 804).

$\mathrm{H}_{4:}$ Marka imajının, müşteri sadakati üzerindeki etkisinde müşteri memnuniyetinin aracılık rolü vardır.

İşletmelerin istikrarlı bir pazar büyüklüğüne sahip olmalarında, yeni müşterilerin kazanılmasında, maliyetlerin düşürülmesinde ve sürdürülebilir büyümeyi sağlamalarında müşteri sadakati önemli bir hale gelmiştir. Sadakatin oluşmasında etkili olan değişkenler arasında müşteri memnuniyeti ve marka imajı yer almaktadır. Marka imajı müşteri memnuniyetini doğrudan etkilemektedir. Beklentileri karşılanan müşteriler işletmeden memnun olarak ayrılırlar. Memnun olan müşteriler işletmeye karşı güçlü bir sadakat geliştirerek tekrar satın alım gerçekleştirir ve işletmeyi başkalarına tavsiye ederler (Sulibhavi ve Shivashankark, 2017a, s. 44). Kısaca, işletmelerin müşterinin zihninde konumlandırmayı amaçladıkları marka imajı ile müşterinin aradığı marka imajının aynı olması durumunda, müşteri marka hakkında olumlu bir tutum benimsemiş olacaktır. Dolayısıyla işletme hedefleri ile müşteri beklentisinin örtüşmesi müşteri memnuniyeti ve müşteri sadakatini pekiştirecektir. $\mathrm{Bu}$ konuyla ilgili literatür incelendiğinde, müşteri memnuniyetinin marka imajı ile müşteri sadakati arasındaki ilişkide aracı rol oynadığı sonucuna ulaşılmıştır (Andreani, Taniaji ve Puspitasari, 2012, s. 70; Lai, Griffin ve Babin, 2009, s. 984; Sondoh Jr ve Diğ., 2007, s. 97; Sulibhavi ve Shivashankark, 2017a, s. 49).

\subsection{Evren ve Örneklem}

2017 yılında 80.810 .525 nüfusun bulunduğu Türkiye'de 77.800 .170 cep telefon kullanıcısının (www.tuik.gov.tr), 40.010.000'u akı1lı telefon kullanıcısı iken bu rakam 
2018 yılında 44.771.000'e ulaşmıştır (Global Mobile Market Report, 2018). Elde edilen bilgilerden hareketle, 44.771.000'ini Apple, Samsung, LG, General Mobile, Lenovo, Asus, Casper, Venus, Nokia, Sony, Huawei, HTC ve diğer akıllı telefon markalarından herhangi birini satın alan veya kullanan tüketiciler (Düzce'de yaşayan) araştırmanın evrenini oluşturmaktadır. 2018 yılı Ocak ayı Düzce İl Nüfus Müdürlüğü tarafından elde edilen verilere dayanılarak il nüfusunu oluşturan 377.610 kişi bulunmaktadır (www.duzcenufus.gov.tr). Bu kişilerden Düzce ilinde ikamet eden 17 yaş ve üzeri herhangi bir akıllı telefon markasını satın alan veya kullanan tüketiciler araştırmanın çalışma evrenini oluşturmuştur. Ancak 17 yaş ve üzeri akıllı telefon kullanıcılarına özgü istatiksel olarak bir bilgiye ulaşılmadığı için Sekaran'ın tablo yönteminden yararlanarak örneklem büyüklüğü belirlenmiştir. Sekaran'ın tablosuna göre 100.000 ve üzeri evren büyüklügünü temsil eden örneklem büyüklüğü 384 ve üzeri olarak belirlenmiştir (Sekaran, 2000). Tüm bu bilgiler 1şığında, araştırmada kolayda örnekleme yöntemi kullanılarak ulaşılan 385 nihai akıllı telefon kullanıcısından oluşan örneklemin evreni temsil edebileceği belirlenmiştir.

\subsection{Veri Toplama Araçları ve Veri Toplama Süreci}

Akıllı telefon kullanıcıların, internet üzerinde daha çok zaman harcaması ve sosyal medyayı daha yaygın bir şekilde kullandıkları düşüncesinden hareketle çevrimiçi anket tekniği ile veriler toplanmıştır (Malhotra, 2010, s. 219). Bu çerçevede oluşturulan çevrimiçi anket formu iki bölümden oluşmaktadır. Anketin ilk bölümünde yer alan, 0,830 güvenilirlik düzeyi olan 5 ifadeden oluşan marka imajı ve 0,850 güvenilirlik düzeyi olan 4 ifadeden oluşan müşteri memnuniyeti değişkenlerine ait ifadeler, Quoquab, Basiruddin ve Abdul Rasid (2014, s. 214) çalışmasından alınmıştır. 0,950 güvenilirlik düzeyi olan ve 5 ifadeden oluşan müşteri sadakati ölçeği Kalyoncuoğlu ve Faiz'in (2017, s. 196), Quoquab, Basiruddin ve Abdul Rasid (2014, s. 214) çalışmasından aldığı ve akıllı telefon kullanıcılarına yönelik adapte ederek Türkçeye uyarladığı ifadelerden oluşmaktadır. Araştırmaya katılan tüketicilerin sosyo-demografik özelliklerini ifade eden 2 ve kullandıkları akıllı telefon markasına ilişkin düşüncelerini ifade eden 1 önerme olmak üzere toplam 3 önermeye yer verilmiştir. Anketi oluşturan ifadeler 5'li Likert tipi ölçek kullanılarak hazırlanmıştır. Çalışmanın veri toplama süreci 3 Nisan ile 22 Nisan 2018 tarihleri arasında gerçekleşmiş ve bu tarihler arasında analize elverişli toplam 385 adet nihai veriye ulaşılmıştır. 385 adet geçerli veriye ulaşılması için öncelikle 60 adet katılımcıya ön test kapsamında hazırlanan anket uygulanmıştır. Yapılan bu öntest sonucunda oluşturulan ölçeklerin tüm tüketiciler tarafından anlaşıldı ğ kanaatine varılmış ve uygulamaya başlanmıştır.

\subsection{Verilerin Analizi}

Ak1llı telefon kullanıcıları üzerinden elde edilen verilerin analizinde SPSS 18 istatistik paket programı kullanılmıştır. Çalışmanın analizinde öncelikle veri setinin detaylı incelenmesi için araştırmaya katılan akıllı telefon kullanıcıların demografik özelliklerini incelemek amacıyla betimsel istatistiklerden frekans analizi kullanılmıştır. Daha sonraki aşamada tanımlayıcı istatistiklerden yararlanarak araştırmanın normal dağılıma sahip olup olmadığını belirlemek için basıklık ve çarpıklık katsayıları belirlenmiştir. Bir sonraki aşamada araştırma sorunsalını oluşturan değişkenleri belirleyebilmek ve araştırma kapsamında incelenen ölçeklerin yapısal geçerliliğini tespit etmek amacıyla keşfedici faktör analizi yapılmıştır. Araştırmaya konu olan değişkenler arasında doğrusal ilişkileri belirlemeye yönelik olarak korelasyon analizi uygulanmıştır. 
Son aşamada araştırma modelinde akıllı telefon pazarında marka imajı ile müşteri sadakati arasındaki ilişkide müşteri memnuniyetinin aracılık rolünü belirlemesine yönelik Baron ve Kenny'in geliştirdikleri Nedensel Adım Yaklaşım yöntemi çerçevesinde basit ve çoklu regresyon analizleri yapılmıştır.

\section{Bulgular ve Yorum}

\subsection{Katılımcıların Demografik Özellikleri}

Tablo 1: Akıllı Telefon Kullanıcıların Demografik Özelliklerine İlişsin Bulgular (n=385)

\begin{tabular}{lcc}
\hline Cinsiyet & $\mathbf{N}$ & $\mathbf{\%}$ \\
\hline Erkek & 122 & 31,7 \\
\hline Kadın & 263 & 68,3 \\
\hline Toplam & $\mathbf{3 8 5}$ & $\mathbf{1 0 0}$ \\
\hline Yaş & $\mathbf{N}$ & $\mathbf{\%}$ \\
\hline $17-23$ & 110 & 28,6 \\
\hline $24-30$ & 177 & 46,0 \\
\hline $31-37$ & 53 & 13,8 \\
\hline $38-44$ & 23 & 6,0 \\
\hline $45-51$ & 19 & 4,9 \\
\hline $52-58$ & 3 & 0,8 \\
\hline Toplam & $\mathbf{3 8 5}$ & $\mathbf{1 0 0}$ \\
\hline
\end{tabular}

Araştırma sürecine dâhil olan katılımcıların demografik özellikleri incelendiğinde kadın katılımcıların $(\% 68,3)$, erkek katılımcılara $(\% 31,7)$ göre araştırmaya daha fazla katılım gösterdiği görülmektedir. Yaş kriterleri baz alındığında katılımcıların \% 46'sının 24-30 yaş aralığını temsil ettiğini bunu takiben \% 28,6'sının 17-23, \% 13,8'inin 31-37, \% 6'sının 38-44, \% 4,9'unun 45-51 ve geriye kalan \%0,8'inin 52-58 yaş aralığını temsil ettiği görülmektedir. Bu sonuçlardan hareketle, araştırma daha çok genç katılımcıların görüşlerini yansıtmaktadır.

\subsection{Katılımcıların Kullandıkları Akıllı Telefon Markasına İlişkin Bulgular}

Tablo 2: Katılımcıların Kullandıkları Akılıı Telefon Markasına İlişsin Bulgular

\begin{tabular}{lcc}
\hline Akıllı Telefon Markası & $\mathbf{N}$ & $\mathbf{\%}$ \\
\hline Apple & 158 & 41,0 \\
\hline Samsung & 116 & 30,1 \\
\hline LG & 21 & 5,5 \\
\hline General Mobile & 12 & 3,1 \\
\hline Casper & 2 & 0,5 \\
\hline Lenovo & 5 & 1,3 \\
\hline Nokia & 2 & 0,5 \\
\hline Sony & 24 & 6,2 \\
\hline Asus & 10 & 2,6 \\
\hline Huawei & 7 & 1,8 \\
\hline HTC & 9 & 2,3 \\
\hline Venus & 3 & 0,8 \\
\hline Diğer & 16 & 4,2 \\
\hline Toplam & $\mathbf{3 8 5}$ & $\mathbf{1 0 0}$ \\
\hline
\end{tabular}

Araştırma sürecine dâhil olan katılımcıların kullandıkları akıllı telefon markaları değerlendirildiğinde \%41'lik büyük bir çoğunluğunu Apple, \%30,1'lik kısmını 
Samsung, \% 6,2'sini Sony, \% 5,5'ini LG, \% 4,2'sini diğer operatör markaları, \% 3,1'ini General Mobile, \% 2,6'sını Asus, \% 2,3'ünü HTC, \% 1,8'ini Huawei, \% 1,3'ünü Lenovo, \% 0,8'ini Venüs geri kalan \% 0,5'lik kısmını Casper ve Nokia marka akıllı telefon kullanıcıları oluşturmaktadır.

\subsection{Araştırma Verilerine İlişkin Tanımlayıcı İstatistikler}

Tabachnick ve Fidell (2013)'e göre araştırmada kullanılan verilerin normal dağılım gösterip göstermediğini belirlemek için çarpıklık ve basıklık katsayılarının -1.5 ile +1.5 arasinda olması gerekmektedir.

Tablo 3: Tanımlayıcı İstatistikler

\begin{tabular}{lcccc}
\hline Ölçekler & Akıllı Telefon Kullanıcıları & & \\
\hline Marka İmajı & Ortalama & Stan.Sapma & Çarpıklık & Basıklık \\
\hline Mí1 & 3,5429 &, 85918 &,- 664 &, 502 \\
\hline Mí2 & 3,72 & 1,027 &,- 900 &, 392 \\
\hline Mí3 & 3,78 &, 978 &,- 985 &, 839 \\
\hline Mí4 & 3,11 & 1,081 &,- 067 &,- 582 \\
\hline Mí5 & 3,43 & 1,166 &,- 405 &,- 694 \\
\hline Müssteri Memnuniyeti & 3,67 &, 978 &,- 720 &, 164 \\
\hline MM1 & 3,6799 &, 90945 &,- 677 &, 420 \\
\hline MM2 & 3,81 & 1,027 &,- 874 &, 447 \\
\hline MM3 & 3,81 & 1,051 &,- 665 &,- 031 \\
\hline MM4 & 3,65 & 1,091 &,- 781 &, 059 \\
\hline Müşteri Sadakati & 3,59 & 1,012 &,- 534 &,- 079 \\
\hline MS1 & 3,6195 & 1,00131 &,- 600 &, 170 \\
\hline MS2 & 3,74 & 1,059 &,- 757 &, 186 \\
\hline MS3 & 3,61 & 1,129 &,- 551 &,- 381 \\
\hline MS4 & 3,65 & 1,087 &,- 729 &, 085 \\
\hline MS5 & 3,48 & 1,127 &,- 445 &,- 509 \\
\hline & 3,39 & 1,212 &,- 361 &,- 778 \\
\hline
\end{tabular}

Tablo 3 incelendiğinde, araştırma kapsamında ele alınan marka imajı, müşteri memnuniyeti ve müşteri sadakatinin ölçeklerine ilişkin veri setinin çarpıklık ve basıklık değerlerinin istenilen sınırlar arasında olduğunu ve bu nedenle verinin normal dağılım özelliğini gösterdiği belirlenmiştir. Değişkenlere yönelik tanımlayıcı istatistikler incelendiğinde akıllı telefon kullanıcılarının marka imajına (Ort: 3,5429), müşteri memnuniyetine (Ort: 3,6799) ve müşteri sadakatine (Ort: 3,6195) yönelik algısının orta düzeyde olduğu görülmektedir.

\subsection{Keşfedici (Açıklayıcı) Faktör Analizi}

Akıllı telefon pazarında marka imajının müşteri sadakati üzerindeki etkisinde müşteri memnuniyetinin aracılık rolünü belirlemek için ilk olarak, oluşturulan ölçüm araçlarının yapı geçerliliği test etmek amacıyla verilere keşfedici faktör analizi uygulanmıştır. Keşfedici faktör analizinin başarılı bir şekilde uygulanabilmesi ve verilerin faktör analizine uygun olup olmadığını belirlemesi için öncelikle Anti-İmaj korelasyon matrisinin köşegen değerlerinin incelenmesi ve bu değerlerin 0,50'nin üzerinde olması gerekmektedir (Dağhan ve Akkoyunlu, 2011, s. 120; Çakır, 2014, s. 9). 
Araştırmada belli bir örneklemden elde edilen değişkenlerin oluşturduğu veri grubunun faktör analizi için uygun olup olmadığını değerlendirmek amacıyla KaiserMeyer-Olkin (KMO) değerine bakılarak sınır değer 0.50 olarak kabul edilmiştir (Field, 2000). Her bir değişken için Bartlett Küresellik Testinin anlamlı olması (p-değeri: .000) maddeler arasındaki korelasyon ilişkilerinin faktör analizi için uygun olduğuna işaret etmektedir (Kalyoncuoğlu ve Faiz, 2016, s. 83). Faktör analizinin başarılı bir şekilde gerçekleştirilebilmesi için araştırma kapsamında ele alınan değişkenlerin açıklanan varyans oranlarının \%50'den büyük ve özdeğerin de 1 ya da 1 'den büyük bir değer alması gerekmektedir (Dölarslan ve Özer, 2014, s. 45). Belirlenen bu faktörler 1şı̆̆ında araştırmaya konu olan değişkenlerin Anti-İmaj ve keşfedici faktör analizi sonuçları değerlendirilmiştir.

Tablo 4: Marka İmajı için Anti-İmaj Korelasyon Matrisi

\begin{tabular}{lccccc}
\hline & Mí1 & Mí2 & Mí3 & Mí4 & Mí5 \\
\hline Mí1 & $\mathbf{8 5 0}$ & & & & \\
\hline Mi்2 &,- 436 & $\mathbf{, 8 3 5}$ & & & \\
\hline Mí3 &,- 088 &,- 192 & $\mathbf{9 1 3}$ & & \\
\hline Mí4 &,- 208 &,- 007 &,- 225 & $\mathbf{8 2 9}$ & \\
\hline Mí5 &,- 192 &,- 269 &,- 037 &,- 466 & $\mathbf{8 3 1}$ \\
\hline
\end{tabular}

Anti-imaj korelasyon matrisinin köşegen değerleri değerlendirildiğinde, marka imajını oluşturan tüm değerlerin 0,5 'ten büyük ve 1'e yakın çıkması marka imajını oluşturan ifadelerin toplam çözüme katkılarının bulunduğunu göstermektedir.

Tablo 5: Marka İmajına İlişkin Faktör Analizi

\begin{tabular}{|c|c|c|c|c|}
\hline \multicolumn{2}{|l|}{ Marka İmajı İfadeleri } & $\begin{array}{l}\text { Faktör } \\
\text { Yükleri }\end{array}$ & $\begin{array}{c}\text { Öz } \\
\text { Değer }\end{array}$ & $\begin{array}{l}\text { Cronbach's } \\
\text { Alpha }\end{array}$ \\
\hline \multicolumn{2}{|c|}{$\begin{array}{l}\text { MI5-Kullandığım akıllı telefon markasının tüketici zihninde } \\
\text { olumlu bir imajı vardır. }\end{array}$} &, 862 & \multirow{5}{*}{3,392} & \multirow{5}{*}{878} \\
\hline \multicolumn{2}{|c|}{$\begin{array}{l}\text { MI1-Kullandığım akıllı telefon markası istikrara sahip } \\
\text { kurumsal bir markadır. }\end{array}$} &, 854 & & \\
\hline \multicolumn{2}{|c|}{ MI2-Kullandığım akıllı telefon markası yenilikçidir. } & 841 & & \\
\hline \multicolumn{2}{|c|}{$\begin{array}{l}\text { MI4-Kullandığım akıllı telefon markasının rakiplerinden daha } \\
\text { iyi bir imaja sahip olduğuna inanıyorum. }\end{array}$} &, 840 & & \\
\hline \multicolumn{2}{|c|}{$\begin{array}{l}\text { MI3-Kullandığım akıllı telefon markası toplum için sosyal bir } \\
\text { katkı yapmaktadır. }\end{array}$} & ,712 & & \\
\hline Değerlendirme Kriterleri & $\begin{array}{l}\text { Kaiser-Meyer-Olkin (KMO): , } 8 \\
\text { Approx. Chi-Square: } 1013,221 \\
\text { Bartlett's Test of Sphericity: ,00 } \\
\text { Aç1klanan Varyans Toplamı: } 67 \\
\text { Extraction Method: Principal Cc } \\
\text { Rotation Method: Varimax with }\end{array}$ & $\begin{array}{l}5 \\
\text { ponent An } \\
\text { aiser Norn }\end{array}$ & $\begin{array}{l}\text { sis } \\
\text { zation }\end{array}$ & \\
\hline
\end{tabular}

Marka imajına yönelik 5 ifadeden oluşan ölçeğin KMO değerinin 0,846 çıkması örneklem sayısının yeterli olduğunu göstermektedir. Bartlett küresellik testi değerinin $(\mathrm{p}=, 000)$ olması marka imajını oluşturan ifadeler arasında yüksek korelasyon olduğunu 
göstermektedir. Faktör analizi sonucunda marka imajını oluşturan 5 ifade tek bir boyut altında toplanarak, açıklanan toplam varyans oranının \% 67,835 ve öz değerin 1'den büyük olduğu sonucuna ulaşılmıştır. Tek boyut altında toplanan marka imajı ölçeğinin Cronbach Alfa değeri hesaplanarak güvenilirlik katsayısının 0,70'ten büyük $(0,878)$ olduğu görülmektedir. Ölçekteki ifadeler arasında iç tutarlılık değerinin yüksek düzeyde olması araştırmada kullanılan marka imajı ölçeğinin güvenilir olduğunu göstermektedir. Faktör analizi sonucunda marka imajını oluşturan ifadelerin 0,862 ile 0,712 faktör yükü aralığında olduğu tespit edilmiştir.

Tablo 6: Müşteri Memnuniyeti için Anti İmaj Korelasyon Matrisi

\begin{tabular}{lcccc}
\hline & MM1 & MM2 & MM3 & MM4 \\
\hline MM1 & $\mathbf{8 1 6}$ & & & \\
\hline MM2 &,- 499 & $\mathbf{, 7 7 6}$ & & \\
\hline MM3 &,- 275 &,- 444 & $\mathbf{8 3 4}$ & $\mathbf{9 3 3}$ \\
\hline MM4 &,- 148 &,- 137 &,- 166 & \\
\hline
\end{tabular}

Anti-imaj korelasyon matrisinin köşegen değerleri değerlendirildiğinde, müşteri memnuniyetini oluşturan tüm değerlerin 0,5 'ten büyük ve 1'e yakın çıkması müşteri memnuniyetini oluşturan ifadelerin toplam çözüme katkılarının bulunduğunu göstermektedir.

Tablo 7: Müşteri Memnuniyetine İlişkin Faktör Analizi

\begin{tabular}{|c|c|c|c|}
\hline Müssteri Memnuniyeti İfadeleri & $\begin{array}{l}\text { Faktör } \\
\text { Yükleri }\end{array}$ & $\begin{array}{c}\text { Öz } \\
\text { Değer }\end{array}$ & $\begin{array}{l}\text { Cronbach's } \\
\text { Alpha }\end{array}$ \\
\hline $\begin{array}{l}\text { MM2-Kullandığım akıllı telefon markası her } \\
\text { beklentilerimi karşılamaktadır. }\end{array}$ & ,920 & \multirow{4}{*}{3,037} & \multirow{4}{*}{,893 } \\
\hline $\begin{array}{l}\text { MM1-Kullandığım akıllı telefon markasından tamamen } \\
\text { memnunum. }\end{array}$ & 904 & & \\
\hline $\begin{array}{l}\text { MM3-Kullandığım akıllı telefon markası şimdiye kadar beni } \\
\text { hayal kırıklığına uğratmadı. }\end{array}$ & ,899 & & \\
\hline $\begin{array}{l}\text { MM4-Kullandığım akıllı telefon markasına ilişkin tecrübem } \\
\text { mükemmeldir. }\end{array}$ & ,752 & & \\
\hline
\end{tabular}

Değerlendirme Kriterleri

Kaiser-Meyer-Olkin (KMO): ,826
Approx. Chi-Square: 1000,975
Bartlett's Test of Sphericity: ,000
Açılanan Varyans Toplamı: 75,925
Extraction Method: Principal Component Analysis
Rotation Method: Varimax with Kaiser Normalization

Müşteri memnuniyetine yönelik 4 ifadeden oluşan ölçeğin KMO değerinin 0,826 çıkması örneklem büyüklüğünün yeterli olduğunu göstermektedir. Bartlett küresellik testi değerinin $(\mathrm{p}=, 000)$ olması müşteri memnuniyetini oluşturan ifadeler arasında yüksek korelasyon olduğunu göstermektedir. Faktör analizi sonucunda müşteri memnuniyetini oluşturan 4 ifade tek bir boyut altında toplanarak, açıklanan toplam varyans oranının \% 75,925 ve öz değerin 1'den büyük olduğu sonucuna ulaş1lmıştır. Tek boyut altında toplanan müşteri memnuniyeti ölçeğinin Cronbach Alfa değeri 
hesaplanarak güvenilirlik katsayısının 0,70 'ten büyük $(0,893)$ olduğu görülmektedir. Ölçekteki ifadeler arasında iç tutarlılık değerinin yüksek düzeyde olması araştırmada kullanılan müşteri memnuniyeti ölçeğinin güvenilir olduğunu göstermektedir. Faktör analizi sonucunda müşteri memnuniyetini oluşturan ifadelerin 0,920 ile 0,752 faktör yükü aralığında olduğu tespit edilmiştir.

Tablo 8: Müşteri Sadakati için Anti İmaj Korelasyon Matrisi

\begin{tabular}{llllll}
\hline & MS1 & MS2 & MS3 & MS4 & MS5 \\
\hline MS1 & $\mathbf{, 9 1 1}$ & & & & \\
\hline MS2 &,- 398 & $\mathbf{8 5 0}$ & & & \\
\hline MS3 &,- 179 &,- 395 & $\mathbf{8 5 1}$ & & \\
\hline MS4 &,- 125 &, 052 &,- 491 & $\mathbf{8 5 7}$ & \\
\hline MS5 &,- 048 &,- 322 &,- 040 &,- 339 & $\mathbf{9 0 4}$ \\
\hline
\end{tabular}

Anti-imaj korelasyon matrisinin köşegen değerleri değerlendirildiğinde, müşteri sadakatini oluşturan tüm değerlerin 0,5 'ten büyük ve 1 'e yakın çıkması müşteri sadakatini oluşturan ifadelerin toplam çözüme katkılarının bulunduğunu göstermektedir.

Tablo 9: Müşteri Sadakatine İlişkin Faktör Analizi

\begin{tabular}{|c|c|c|c|c|}
\hline \multicolumn{2}{|l|}{ Müşteri Sadakati İfadeleri } & $\begin{array}{l}\text { Faktör } \\
\text { Yükleri }\end{array}$ & Öz Değer & $\begin{array}{l}\text { Cronbach's } \\
\text { Alpha }\end{array}$ \\
\hline \multicolumn{2}{|c|}{$\begin{array}{l}\text { MS3-Kullandığım akıllı telefon markasını herkese tavsiye } \\
\text { ederim. }\end{array}$} & ,925 & \multirow{5}{*}{4,009} & \multirow{5}{*}{,937 } \\
\hline \multicolumn{2}{|c|}{$\begin{array}{l}\text { MS2-Eğer yeni bir akıllı telefon almam gerekirse, yine şu an } \\
\text { kullandığım markayı tercih ederim. }\end{array}$} & ,915 & & \\
\hline \multicolumn{2}{|c|}{$\begin{array}{l}\text { MS4- Akıllı telefon almayı düşünen arkadaşlarımı, şu an } \\
\text { kullandığım akıllı telefon markasını almaları yönünde teşvik } \\
\text { ederim. }\end{array}$} &, 892 & & \\
\hline \multicolumn{2}{|c|}{ MS1-Bu akıllı telefon markasını kullanmaya devam edeceğim. } & 875 & & \\
\hline \multicolumn{2}{|c|}{$\begin{array}{l}\text { MS5- Diğer akıllı telefon markalarının fiyatları daha ucuz olsa } \\
\text { da yine şu anki akıllı telefon markamı kullanmaya devam } \\
\text { ederim. }\end{array}$} &, 869 & & \\
\hline Değerlendirme Kriterleri & \multicolumn{3}{|c|}{$\begin{array}{l}\text { Kaiser-Meyer-Olkin (KMO): , } 873 \\
\text { Approx. Chi-Square: } 1699,323 \\
\text { Bartlett's Test of Sphericity: ,000 } \\
\text { Açılanan Varyans Toplamı: } 80,189 \\
\text { Extraction Method: Principal Component Analysis } \\
\text { Rotation Method: Varimax with Kaiser Normalization }\end{array}$} & \\
\hline
\end{tabular}

Müşteri sadakatine yönelik 5 ifadeden oluşan ölçeğin KMO değerinin 0,873 çıkması örneklem büyüklüğünün yeterli olduğunu göstermektedir. Bartlett küresellik testi değerinin $(\mathrm{p}=, 000)$ olması müşteri sadakatini oluşturan ifadeler arasında yüksek korelasyon olduğunu göstermektedir. Faktör analizi sonucunda müşteri sadakatini oluşturan 5 ifade tek bir boyut altında toplanarak, açıklanan toplam varyans oranının \% 80,189 ve öz değerin 1'den büyük olduğu sonucuna ulaşılmıştır. Tek boyut altında toplanan müşteri sadakati ölçeğinin Cronbach Alfa değeri hesaplanarak güvenilirlik 
katsayısının 0,70 'ten büyük $(0,937)$ olduğu görülmektedir. Ölçekteki ifadeler arasında iç tutarlılık değerinin yüksek düzeyde olması araştırmada kullanılan müşteri sadakati ölçeğinin güvenilir olduğunu göstermektedir. Faktör analizi sonucunda müşteri sadakatini oluşturan ifadelerin 0,925 ile 0,869 faktör yükü aralığında olduğu tespit edilmiştir.

\subsection{Korelasyon Analizi}

Araştırmaya konu olan değişkenler marka imajı, müşteri memnuniyeti ve müşteri sadakati arasındaki ilişkinin derecesini ve yönünü belirlemek için korelasyon analizi yapılmıştır.

Tablo 10: Korelasyon Analizine İlişkin Bulgular

\begin{tabular}{lccc}
\hline & Marka İmajı & $\begin{array}{c}\text { Müşteri } \\
\text { Memnuniyeti }\end{array}$ & $\begin{array}{c}\text { Müşteri } \\
\text { Sadakati }\end{array}$ \\
\hline Marka İmajı & 1 & & \\
\hline Müşteri Memnuniyeti &, $647^{* *}$ & 1 & 1 \\
\hline Müşteri Sadakati &, $674^{* *}$ &, $835^{* *}$ & 1 \\
\hline
\end{tabular}

Anlamlllkk Düzeyi $p<0.01$

Korelasyon analizi sonucu en yüksek ilişki müşteri memnuniyeti ve müşteri sadakati arasında 0,835 yüksek düzeyde anlamlı ve pozitif yönde bir ilişki bulunurken, sırasıyla marka imajı ve müşteri sadakati arasında 0,674 orta düzeyde anlamlı ve pozitif yönde bir ilişki olduğu ve son olarak marka imajı ile müşteri memnuniyeti arasında 0,647 orta düzeyde anlamlı ve pozitif yönde bir ilişki olduğu sonucuna ulaşılmıştır.

\subsection{Regresyon Analizi}

Araştırmada akıllı telefon pazarında marka imajının müşteri sadakati üzerindeki etkisinde müşteri memnuniyetinin aracılık rolünü tespit etmek temel amaçtır. Müşteri memnuniyetinin aracılık rolünü belirlemek için Baron ve Kenny (1986)'nin önerdiği dört aşamalı yaklaşım olan Nedensel Adım Yaklaşımı çerçevesinde basit ve çoklu regresyon analizleri uygulanmıştır (Kalyoncuoğlu, 2017, s. 393). Aracı değişkeni belirlemek için Baron ve Kenny'nin (1986, ss. 1174-1176) önerdiği dört aşamalı yönteme göre;

- $\quad$ Birinci adımda, bağımsız değişkenin bağımlı değişken üzerinde istatiksel olarak anlamlı bir etkiye sahip olması,

- $\quad$ İkinci adımda, bağımsız değişkenin aracı değişken üzerinde istatiksel olarak anlamlı bir etkiye sahip olması,

- $\quad$ Üçüncü adımda, aracı değişkenin bağımlı değişken üzerinde istatiksel olarak anlamlı bir etkiye sahip olması gerekmektedir.

- Son aşama olan dördüncü adımda ise bağımsız değişken ile birlikte aracı değişkeninde modele dâhil edilmesiyle birlikte bağımlı değişken üzerindeki etkiye bakılarak aracılık rolü belirlenmektedir. Bu durumda, ilk adımda bağımsız değişkenin bağımlı değişken üzerinde istatiksel olarak anlamlı olan etkisi, aracı değişkenin modele 
dâhil edilmesiyle birlikte bağımsız değişkenin bağımlı değişken üzerinde anlamlı olmayan bir etkisinin ortaya çıkması durumunda aracı değişken "tam aracılık" rolünü üstlenmektedir. Ancak bağımsız değişkenin bağımlı değişken üzerindeki istatiksel olarak anlamlı olan etkisinde bir azalma meydana gelmesi durumunda aracı değişken "k1smi arac1l1k" rolünü üstlenmektedir.

Baron ve Kenny'nin (1986) aracı değişkeni belirlemek için oluşturulan modelden hareketle basit ve çoklu regresyon analizi uygulanmıştır;

Tablo 11: Regresyon Analizi Sonuçları

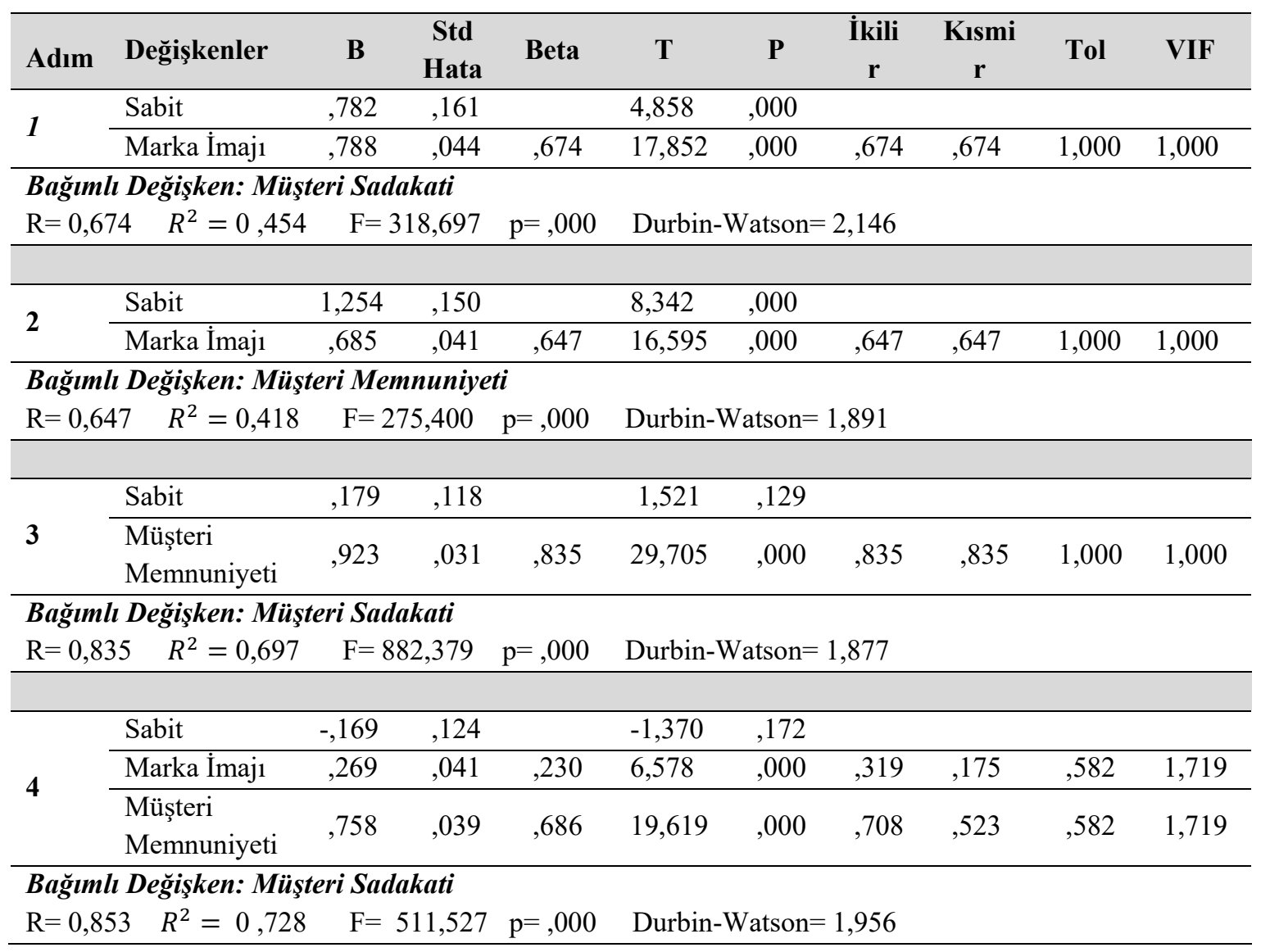

Regresyon analizleri sonucunda, aracı değişkenin belirlenmesinin birinci adımında marka imajının müşteri sadakati üzerinde pozitif yönde anlamlı bir etkisinin $\left(R^{2}=0,454, \beta=0,674, \mathrm{p}<0,01\right)$ olduğu ve müşteri sadakati değişkenindeki toplam varyansın \% 45,4'ünü açıkladığı görülmektedir. Bu bulgular 1şığında; $H_{1}$; "Marka imajının müşteri sadakati üzerinde pozitif yönde bir etkisi vardır." hipotezi kabul edilmiştir. İkinci adımda marka imajının müşteri memnuniyeti üzerinde pozitif yönde anlamlı bir etkisinin $\left(R^{2}=0,418, \beta=0,647, \mathrm{p}<0,01\right)$ olduğu ve müşteri memnuniyeti değişkenindeki toplam varyansın \% 41,8'ini açıkladığı görülmektedir. Bu bulgular 1şığında; $\mathrm{H}_{2}$; "Marka imajının müşteri memnuniyeti üzerinde pozitif yönde bir etkisi vardır" hipotezi kabul edilmiştir. Üçüncü adımda müşteri memnuniyetinin müşteri sadakati üzerinde pozitif yönde anlamlı bir etkisi $\left(R^{2}=0,697, \beta=0,835, p<0,01\right)$ olduğu ve müşteri sadakati değişkeninin toplam varyansının \% 69,7'sini açıkladığ 1 
görülmektedir. $\mathrm{Bu}$ bulgular 1şığında; $H_{3}$; "Müşsteri memnuniyetinin müşteri sadakati üzerinde pozitif yönde bir etkisi vardır" hipotezi kabul edilmiştir.

Dördüncü adımda müşteri memnuniyetinin aracı değişken etkisinden bahsedebilmemiz için tüm aşamaların sonuçlarının birlikte değerlendirilmesi gerekmektedir. Buradan hareketle kabul edilen $H_{1}, H_{2}$ ve $H_{3}$ hipotezleri sonucunda müşteri memnuniyetinin, marka imajı ile müşteri sadakati arasında aracı değişken etkisinin araştırılması için uygun olduğu sonucuna ulaşılmıştır. Adım 1 ve Adım 4 karşılaştırıldığında, Adım 1'de marka imajı değişkeninin müşteri sadakati üzerindeki etkisi $\beta=0.674, \mathrm{t}=17,852, \mathrm{p}<0.01$ iken, Adım 4'te bu etkinin $\beta=0.230, \mathrm{t}=6.578, \mathrm{p}<$ 0.01 ' e düştügü görülmektedir. Bu bulguya göre, müşteri memnuniyetinin, marka imaj1 ve müşteri sadakati arasında "kısmi aracı" değişken olduğu sonucuna ulaşılmıştır. Buradan hareketle, $H_{4}$; "Marka imajının, müşteri sadakati üzerindeki etkisinde müşteri memnuniyetinin aracılık rolü vardır” hipotezi kabul edilmiştir. Bir diğer ifadeyle, marka imajının müşteri memnuniyetini arttırdığını ve müşteri memnuniyetinin de müşteri sadakatini arttırdığı doğrulanmıştır. Tüm şartların sağlanmasından sonra son aşamada aracılık modelinin istatistiksel olarak anlamlılığ kontrol etmek için Sobel Testi kullanılmıştır (Kalyoncuoğlu, 2017, s. 394; Gürbüz ve Şahin, 2017, s. 288). Sobel Testinin hesaplanması sonucunda, aracilik etkisinin istatistiksel olarak anlamlı $(\mathrm{z}=14,570, \mathrm{p}<0,01)$ olduğu tespit edilmiştir. Adım 4'teki araştırma sonucundan elde edilen bulgular değerlendirildiğinde VIF değerlerinin $(1,719) 10$ 'dan yüksek bir değer ve tolerance değerlerinin (0.582) 0.20 'den daha düşük bir değer olmadığı için bağımsız değişkenler arasında çoklu bağlantılılık sorununun olmadığını göstermektedir. Ayrıca Adım 1, Adım 2, Adım 3 ve Adım 4'teki sırasıyla Durbin-Watson katsayıları (2,146, $1,891,1,877$ ve 1,956) bağımsız değişkenler ile hata terimleri arasında sorunlu bir ilişsinin olmadığı sonucuna ulaşılmıştır.

\section{Sonuç ve Öneriler}

Teknolojik değişimin sürekli olduğu ve öngörülemediği rekabetçi pazarlarda işletmeler için önemli olan karlılığı attırmak ve sürdürülebilirliği sağlamaktır. Ancak günümüz rekabetçi pazar koşullarında işletmeler bu amaçlarını yerine getirmekte zorlanmaktadırlar. $\mathrm{Bu}$ amacı yerine getirebilmek için var olan müşteri kitlesini korumak, tüketiciler tarafından tercih edilebilmek ve tekrar satın alma isteği uyandırabilmek için müşteri sadakatinin oluşturulması önem arz etmektedir. Müşteri sadakatinin belirlenmesinde en önemli değişkenler şüphesiz müşteri memnuniyeti ve marka imajıdır. Literatür incelendiğinde, marka imajının müşteri sadakati üzerindeki etkisinde müşteri memnuniyetinin aracılık rolü üstlendiği sonucuna ulaşılmıştır (Andreani, Taniaji ve Puspitasari, 2012, s. 70; Lai, Griffin ve Babin, 2009, s. 984; Sondoh Jr ve Diğ., 2007, s. 97; Sulibhavi ve Shivashankark, 2017a, s. 49). Bu konu ile ilgili yapılan çalışmalar incelendiğinde, Sondoh Jr. vd. (2007) çalışmalarında, Malezyalı kadınlar üzerinde renkli kozmetik ürünleri bağlamında marka imajı faydalarının memnuniyet ve sadakat niyeti üzerindeki etkisini incelemişlerdir. Araştırma sonucunda marka imajı faydaları ile müşteri sadakati arasındaki ilişkide müşteri memnuniyetinin aracı değişken olduğu tespit edilmiştir. Andreani, Taniaji ve Puspitasari (2012), McDonald's üzerinde yaptıkları çalışmalarında marka imajının müşteri sadakati üzerindeki etkisinde müşteri memnuniyetinin aracı değişken olduğunu tespit etmişlerdir. Sulibhavi ve Shivashankark (2017a) çalışmalarında Hubli-Dharwad şehrinde müşterinin özel etiket markalarına yönelik marka imajı algıları ile memnuniyet ve bağlılık arasındaki ilişkiyi incelemişlerdir. Araştırma sonucunda, memnuniyetin marka imajı ile 
müşteri sadakati arasındaki ilişkide aracı değişken olduğunu tespit etmişlerdir. Marka imajının, işletme ile müşteri arasındaki bağı güçlendirmesi çalışmanın temel hareket noktasıdır. Bu doğrultuda ele alınan çalışmada, çalışma alanı kısıtlı olan ve her geçen gün büyüyen akıllı telefon sektöründe marka imajının müşteri sadakati üzerindeki etkisinde müşteri memnuniyetinin aracılık etkisine sahip olup olmadığ incelenmiştir.

Baron ve Kenny (1986)'nin dört aşamalı regresyon modelinin ilk aşama sonucu; marka imajının müşteri sadakati üzerinde pozitif ve anlamlı bir etkisinin olduğu yönündedir. İkinci aşama sonucu, marka imajının müşteri memnuniyeti üzerinde pozitif ve anlamlı bir etkisinin olduğu yönündedir. Üçüncü aşama sonucu, müşteri memnuniyetinin müşteri sadakati üzerinde pozitif ve anlamlı bir etkisinin olduğu yönündedir. Dördüncü aşamada yer alan araştırmanın odaklandığı asıl sonuç ise, marka imajının müşteri sadakati üzerindeki etkisinde müşteri memnuniyetinin kısmi aracı değişken olduğu yönündedir.

Çalışma ile akıllı telefon pazarında faaliyet gösteren işletmelere ve genel anlamda sektöre katkı sağlaması beklenilen en temel bulgu, marka imajının müş̧eri sadakatini doğrudan etkilediği sonucudur. Akıllı telefon kullanıcılarının bir akıllı telefondan bekledikleri performans ve aldıkları hizmetlerin öncesinde dikkat ettikleri husus markanın imajıdır. Olumlu marka imajına sahip akıllı telefon markaları daha çok tercih edilmektedir. Aslında imaj satın alma niyetinde ve satın almanın sürekli hale gelmesini sağlayarak bağlılık yaratmada önemli rol oynamaktadır. Öte yandan marka imajının müşteri memnuniyeti üzerinden müşteri sadakati oluşturulduğu bilgisi ise akıllı telefon pazarındaki uygulayıcılar için son derece değer arz eden bir sonuçtur. Müşteri memnuniyetinin aracılık rolü, akıllı telefon pazarı için şu şekilde tanımlanabilir.

Müşteri zevklerinin ve tercihlerinin her geçen gün değiştiği bir ortamda bu değişime uygun yeni teknolojiye sahip akıllı telefonlar üretmek, ak1llı telefonda mevcut sunulanların yanı sıra farklı özellikler ve satış sonrası servis imkânlarını üst düzeyde sunmak müşteri memnuniyetini getiren etkenler olurken; pozitif bir marka imaj1 yaratmak ve tüm topluma bunu yaymak da memnuniyeti sağlayan ve memnuniyet üzerinden sadakat yaratan bir faktör olmaktadır. Müşteriler marka imajı yüksek ürünler kullandıklarında bulundukları sosyal çevrede kendilerine prestij katıyor olmasını önemsemekte ve tercihlerinde gözetmektedir. Özellikle de akıllı telefon pazarında olduğu gibi pazarda belli başlı markalar öne çıkıyor ve bu markaları kullanmak müşteriye toplum içerisinde saygınlık kattığı ve kendi imajını da yükselttiği düşüncesi veriyor ise o markaların imajı daha da önem kazanmaktadır. Markalar müşteri kazanmak ve mevcut müşteriyi kaybetmemek için çalışırken rekabet ortamında birbirini zedeleyici davranışlarda bulunduklarında imajları üzerinde olumsuz etkiler oluşturabilmektedir. Ancak akıllı telefon markaları üzerine tüm olumsuz imaj algısına rağmen işletmelerin müşterinin tüm beklentisini belirleyip, bu beklentileri en iyi şekilde karş1laması sonucu müşteriler işletmeye karşı sadakat göstermektedir. Kısacası marka imajında yaşanılacak herhangi bir olumsuz durumda müşteri eğer akıllı telefon markasından memnun kalmışsa bu olumsuzlukları bertaraf ederek müşterilerin bir sonraki tercihlerinde de aynı markaya sıklıkla yöneleceklerine ilişkin güçlü bir durum oluşturabileceği söylenebilmektedir. Dolayısıyla marka imajı ile sadakat arasındaki etkinin sağlanabilmesinde müşterilerin memnuniyetini arttıracak stratejiler uygulanması gerekmektedir. 
Çalışmadan elde edilen sonuçlar ve öncesinde gerçekleştirilen literatür taraması neticesinde gelecekte bu alanda çalışmalar gerçekleştirecek olan araştırmacılara marka imaj1, müşteri memnuniyeti ve müşteri sadakati değişkenlerine ek olarak markaya duyulan güven ve marka kişiliğinin de eklenerek yeni modeller geliştirilebileceği önerisinde bulunulabilir. Marka kişiliği, tüketiciler üzerinde marka hakkında edinilen duygular sayesinde markaların daha yakın olmasını sağlar ve memnuniyeti etkileme gücüne sahiptir. Markaya duyulan güven ise, marka hakkında edinilen duyguların pekişmesini sağlayarak müşterilerde sadakati güçlendirmektedir.

Akıllı telefon pazarında yer alan işletmelere ise pazarlama stratejisi oluştururken bütünleşik olarak marka stratejilerini de ele almaları gerektiği çalışma bulguları doğrultusunda önerilebilir. Çünkü marka kavramı, işletmeye ve ürüne fayda sunmanın ötesinde imaj, saygınlık, prestij katmak gibi tüketicilere soyut değerlerde sunmaktadır. $\mathrm{Bu}$ nedenle, markanın tüketici gözünde algısını ifade eden marka imajı kavramına dikkat çekilmelidir. Müşteri bir işletmeden ürün satın alacağı zaman kendi izlenimleri sonucu oluşturduğu marka imajı sayesinde satın alma gerçekleştirmektedir. Bu noktada, işletmeler, tüketici zihninde akıllı telefon markasını yeterli fonksiyonel özelliklere sahip, ihtiyaç karşılayıcı ve yüksek kaliteli gibi özelliklerle şekillendirebilmek için tutundurma çabaları olan halkla ilişkiler, reklam, tanıtım gibi faaliyetlerle akıllı telefon marka imajını olumlu konumlandırabilecek stratejiler geliştirmelidir. $\mathrm{Bu}$ açıdan değerlendirildiğinde, her yıl pazarda ilk iki sırada yer alan Apple ve Samsung akıllı telefon markaları aynı zamanda Interbrand (2017) verilerine göre, dünya çapında yer alan markalar arasında ilk 10 da yer bulmaktadır (www.interbrand.com). Hem araştırma verilerine göre hem de dünya genelinden elde edilen verilere göre Apple ve Samsung marka akıllı telefonların öne çıkarak birçok müşteri tarafindan tercih edildiği ve geri kalan on bir markanın neden kullanım oranının bu iki markaya kıyasla düşük olduğu irdelenmesi gereken önemli konular arasındadır.

Teknoloji sayesinde herhangi bir işletmenin çıkardığı ürünün rakip ürünlerden farklılaşmasını sağlamanın zor olması nedeniyle de marka imajı kavramı öne çıkmaktadır. Müşteriler farklı olanı satın almak isterken imajın kattığ 1 farklılığı da göz önünde bulunduracaktır. Akıllı telefonların sürekli yenilendiğini düşünüldüğünde müşteriye farklılık katacak olan şeyler imaj gibi soyut değerler olacaktır.

\section{Kaynakça}

Anderson, E. W., Fornell, C., Rust, R. T. (1997). "Customer Satisfaction, Productivity, and Profitability: Differences Between Goods and Services", Marketing Science, Vol. 16, No. 2, 129-145.

Andreani, F., Taniaji, T. L., Puspitasari, R. N. M. (2012). “The Impact of Brand Image Towards Loyalty with Satisfaction as a Mediator in McDonald's", Jurnal Manajemen dan Kewirausahaan, Vol.14, No. 1, 64-71.

Andreassen, W.T., Lindestad, B. (1998). "Customer Loyalty and Complex Services: The Impact of Corporate Image on Quality, Customer Satisfaction and Loyalty for Customers with Varying Degrees of Service Expertise", International Journal of Service Industry Management, Vol.9, No.1,7-23.

Baron, R. M., Kenny, D. A. (1986). "The Moderator-Mediator Variable Distinction in Social Psychological Research: Conceptual,Strategic, and Statistical 
Considerations", Journal of Personality and Social Psychology, Vol.51, No.6, 1173-1182.

Bruhn, M., Grund, M. A. (2000). "Theory, Development and Implementation of National Customer Satisfaction Indices: The Swiss Index of Customer Satisfaction (SWICS)", Total Quality Management, Vol. 11, No. 7, 1017-1028.

Can, E. (2007). "Marka ve Marka Yapılandırma", Marmara Üniversitesi İktisadi ve İdari Bilimler Dergisi, Cilt. 22, Sayı: 1, 225-237.

Chen, C. F., Cheng, L. T. (2012). "A Study on Mobile Phone Service Loyalty in Taiwan”, Total Quality Management \& Business Excellence, Vol. 23, No. (7-8), 807-819.

Çakır, A. (2014). Faktör Analizi. Doktora Tezi İstanbul Ticaret Üniversitesi Sosyal Bilimler Enstitüsü. İstanbul.

Dağhan, G., Akkoyunlu, B. (2011). “Maggie Mcvay Lynch Öğrenme Stili Envanterinin Türkçe’ye Uyarlanma Çalışması”, Hacettepe Üniversitesi Eğitim Fakültesi Dergisi, Cilt. 40, Say1: 40, 117-126.

Değermen, A. (2004). Hizmet Kalitesi ile Müşteri Sadakatinin Sağlanması ve GSM Sektöründe Bir Uygulama, Doktora Tezi, İstanbul Üniversitesi Sosyal Bilimler Enstitüsü, İstanbul

Deng, Z., Lu, Y., Wei, K. K., Zhang, J. (2010). "Understanding Customer Satisfaction and Loyalty: An Empirical Study of Mobile Instant Messages in China", International Journal of Information Management, Vol. 30, No. 4, 289-300.

Dick, A. S., Basu, K. (1994). “Customer Loyalty: Toward an Integrated Conceptual Framework", Journal of the Academy of Marketing Science, Vol. 22, No. 2, 99113.

Dölarslan, E. Ş., Özer, A. (2014). "Hizmet Kalitesi, Tatmin ve Güvenin Daha Fazla Ödeme Eğilimi Üzerindeki Etkileri”, Anadolu Üniversitesi Sosyal Bilimler Dergisi, Cilt. 14, Say1: 1, 31-58.

Erciş, S., Geçikli, F., Çat, A. K. (2016). "Tüketicilerin Mağaza İmajı Algıları ile Mağaza Sadakati Arasındaki İlişkinin Belirlenmesi: Bir Alışveriş Merkezinde Uygulama”, Abant Kültürel Araştırmalar Dergisi, Cilt. 1, Sayı: 2, 46-56.

Eren, S. S., Eker, B. U. S. (2012). "Kurumsal Sosyal Sorumluluk Algisının Marka İmaj1, Algılanan Değer, Müşteri Tatmini ve Marka Sadakatine Etkisi Üzerine Bir Saha Araştırması: X Markası Örneği”, Süleyman Demirel Üniversitesi İktisadi ve İdari Bilimler Fakültesi Dergisi, Cilt. 17, Sayı: 2, 451-472.

Ergülşen, G. (2014). Marka İmajının Tüketicilerin Satın Alma Davranışı Üzerindeki Etkisi. Yüksek Lisans Tezi, Ege Üniversitesi Sosyal Bilimler Enstitüsü, İzmir.

Faullant, R., Matzler, K., Füller, J. (2008). "The Impact of Satisfaction and Image on Loyalty: The Case of Alpine Ski Resorts”, Managing Service Quality: An International Journal, Vol. 18, No. 2, 163-178.

Field, A. (2000). Discovering Statistics Using SPSS for Windows. London, Thousand Oaks, Sage Publications, New Delhi. 
Fornell, C. (1992). "A National Customer Satisfaction Barometer: The Swedish Experience", The Journal of Marketing, Vol. 56, No. 1, 6-21.

Genoveva, (2005). "Analyzing of Customer Satisfaction and Customer Loyalty Based on Brand Image and Perceived Service Quality", Journal of US-China Public Administration, Vol. 12, No. 6, 497-508.

Gürbüz, S., Şahin, F. (2017). Sosyal Bilimlerde Araştırma Yöntemleri (4.Baskı), Seçkin Yayınc1lı, Ankara.

Hu, H. H., Kandampully, J., Juwaheer, T. D. (2009). "Relationships and Impacts of Service Quality, Perceived Value, Customer Satisfaction, and Image: An Empirical Study", The Service Industries Journal, Vol. 29, No. 2, 111-125.

Hung,C.(2008). "The Effect of Brand Image on Public Relations Perceptions and Customer Loyalty", International Journal of Management, Vol. 25, No. 2, 237246.

Hussain, R. (2016). “The Mediating Role of Customer Satisfaction: Evidence from The Airline Industry", Asia Pacific Journal of Marketing and Logistics, Vol. 28, No. 2, 234-255.

Ibanez, V. A., Hartmann, P., Calvo, P. Z. (2006). "Antecedents of Customer Loyalty in Residential Energy Markets: Service Quality, Satisfaction, Trust and Switching Costs", The Service Industries Journal, Vol. 26, No. 6, 633-650.

Kalyoncuoğlu, S., Faiz, E. (2016). "Hizmet Kalitesinin Kurumsal İmaja Etkisi: Kamu ve Özel Mevduat Bankaları Üzerine Bir Araştırma”, Pazarlama ve Pazarlama Araştırmaları Dergisi, Sayı: 17, 67- 103.

Kalyoncuoğlu, S., Faiz, E. (2017). “Müşterilerin Sadakat Geliştirme Eğilimlerini Etkileyen Faktörlerin Belirlenmesi: Akıllı Telefon Kullanıcıları Üzerinde Bir Araştırma", Gazi Üniversitesi İktisadi ve İdari Bilimler Fakültesi Dergisi, Cilt. 19, Say1: 1, 184-210.

Kalyoncuoğlu, S. (2017). "Markaya Duyulan Güven ile Marka Sadakati İlişkisinde Marka Aşkının Aracılık Rolü: Starbucks Markası Üzerine Bir Araştırma". Journal of Tourism and Gastronomy Studies, Cilt. 5, Say1: 4, 383402.

Kim, M. K., Park, M. C., Jeong, D. H. (2004). "The Effects of Customer Satisfaction and Switching Barrier on Customer Loyalty in Korean Mobile Telecommunication Services", Telecommunications Policy, Vol. 28, No. 2, 145 159.

Lai, F., Griffin, M., Babin, B. J. (2009). "How Quality, Value, Image, and Satisfaction Create Loyalty at a Chinese Telecom", Journal of Business Research,Vol. 62, No. 10, 980-986.

Liat, C. B., Mansori, S., Huei, C. T. (2014). “The Associations Between Service Quality, Corporate Image, Customer Satisfaction, and Loyalty: Evidence From the Malaysian Hotel Industry", Journal of Hospitality Marketing \& Management, Vol. 23, No. 3, 314-326. 


$$
\text { G. Uludağ - E. Faiz - K. Çatı 10/4 (2018) 575-599 }
$$

Lin, H. H., Wang, Y. S. (2006). "An Examination of The Determinants of Customer Loyalty in Mobile Commerce Contexts", Information \& Management, Vol. 43, No. 3, 271-282.

Malhotra, N. K. (2010). Marketing Research: An Applied Orientation (6th Edition). New Jersey: Pearson Education.

Meenaghan, T. (1995). "The Role of Advertising in Brand Image Sevelopment", Journal of Product \& Brand Management, Vol. 4, No. 4, 23-34.

NQRC, (1995). American Consumer Satisfaction Index Methodology Report, University of Michigan Business School, Ann Arbor, MI.

Quoquab, F., Basiruddin, R., Abdul Rasid, S. Z. (2014). "Striving for Customer Loyalty: What are the Building Blocks? Innovation", Communication and Engineering, 203-208.

Sekaran, U. (2000). Research Methods for Business: A Skill-Building Approach, UK: Wiley\&Sons.

Sondoh Jr, S. L., Omar, M. W., Wahid, N. A., Ismail, I., Harun, A. (2007). "The Effect of Brand Image on Overall Satisfaction and Loyalty Intention in The Context of Color Cosmetic", Asian Academy of Management Journal, Vol. 12, No. 1, 83107.

Stan, V., Caemmerer, B., Cattan-Jallet, R. (2013). "Customer Loyalty Development: The Role of Switching Costs", Journal of Applied Business Research, Vol. 29, No.5, 1541-1554.

Sulibhavi. B., Shivashankar, K. (2017a). “The Impact of Brans Image On Customer's Loyalty Towards Private Label Brands: The Mediating Effect of Satisfactin: Hubl1- Dharwad Conglomerate City of Karnataka", International Journal of Marketing \& Financial Management, Vol. 5, No. 8, 43-50.

Sulibhavi. B., Shivashankar, K. (2017b). "Brand Image and Trust on Customers Loyalty: A Study on Private Label Brands in Hubli-Dharwad Conglomerate City of Karnataka", Journal of Engineering Research and Application, Vol. 7, No. 9, 01-06.

Tabachnick, B. G. ve Fidell, L. S. (2012). Using Multivariate Statistics (6. bs.). New Jersey: Pearson.

Tabaku, E., Çerri, S. (2015). “An Empirical Investigation of Customer Loyalty in Telecommunication Industry in Albania", Mediterranean Journal of Social Sciences, Vol. 6, No. 1, 224-231.

Tu, Y. T., Wang, C. M., Chang, H. C. (2012). "Corporate Brand Image and Customer Satisfaction on Loyalty: An Empirical Study of Starbucks Coffee in Taiwan", Journal of Social and Development Sciences, Vol. 3, No.1, 24-32.

Uç, H., Tolon, M. (2016). "Kullanılan Akıllı Telefon Markasının Çıkardığı Yeniliklere Göre Tüketicilerin Kalite Algılarını Belirlemeye Yönelik Bir Araştırma. İktisadi ve İdari Bilimler Fakültesi Dergisi, Cilt.18, Sayı: 1, 27-48.

Yalçın, İ., Koçak, S. (2009). "Niğde Devlet Hastanesinde Müşteri Memnuniyeti Üzerine Bir Araştırma”, Niğde Üniversitesi İİBF Dergisi, Cilt. 2, Sayı: 2, 19-41. 
Yang, Z., Peterson, R. T. (2004). "Customer Perceived Value, Satisfaction, and Loyalty: The Role of Switching Costs", Psychology \& Marketing, Vol. 21, No. 10, 799822.

Yetkil, E. M. (2017). Hizmet Kalitesi ve Marka İmajının Müşteri Sadakatine Etkisi: Bankacılık Sektöründe Bir Uygulama. Yüksek Lisans Tezi, Türk Hava Kurumu Üniversitesi Sosyal Bilimler Enstitüsü, Ankara.

Global Mobile Marketing Report(2018). www.newzoo.com/ Erişim Tarihi:02.02. 2018 www.duzcenufus.gov.tr/ Erișim Tarihi: 02.02. 2018

www.tuik.gov.tr/ Erişim Tarihi: 02.02. 2018

www.interbrand.com/ Erişim Tarihi: 28.05.2018 


\title{
The Mediating Role of Customer Satisfaction in the Impact of Brand Image on Customer Loyalty in the Smartphone Market
}

\author{
Gamze ULUDA $\breve{G}$ \\ Düzce University \\ Institute of Social Sciences \\ Düzce, Turkey \\ orcid.org/0000-0002-6504-1079 \\ gamzeuludag1993@hotmail.com
}

\author{
Emel FAIZ \\ Düzce University \\ Faculty of Business Administration \\ Düzce, Turkey \\ orcid.org/0000-0002-1911-7706 \\ emelgokmenoglu@duzce.edu.tr
}

\author{
Kahraman ÇATI \\ İnönü University \\ Faculty of Economic and Administration Sciences \\ Malatya, Turkey \\ orcid.org/0000-0002-7440-5436 \\ kahraman.cati@inonu.edu.tr
}

\section{Extensive Summary}

\section{Introduction}

Customer loyalty is a concept that has become important both in manufacturing enterprises and in service enterprises. Customer loyalty is one of the basic elements of competitiveness in smartphone business as in businesses operating in the all sector. Because the smartphone industry is growing day by day and is at the forefront of the sectors with the highest competition (Kalyoncuoğlu and Faiz, 2017, s. 128). So for businesses has become important to examine the effects on customer loyalty in order to maintain the existing customer base and to gain advantage in a competitive environment. Between the important determinants of customer loyalty are brand image and customer satisfaction concepts. In this study, this two variable which have the greatest effect on customer loyalty, were examined.

The concept of customer satisfaction, which is most effective on customer loyalty, is not always effective on its own. For this reason, the concept of brand image which affects both customer satisfaction and loyalty is included in the research. There are many studies in the literature investigating the positive effect of brand image and customer satisfaction on customer loyalty. However, the number of studies examining the mediating role of customer satisfaction in the influence of brand image on customer loyalty is limited in the literature. The basic purpose of the research created at this point, determining the mediating role of customer satisfaction in the impact of brand image on customer loyalty in the smartphone market. There are three sub-objectives in the research, (1) determining the effect of brand image on customer loyalty in the smartphone market, (2) determining the effect of brand image on customer satisfaction in the smartphone market, (3) determining the effect of customer satisfaction on customer loyalty in the smartphone market. 


\section{Methodology}

According to the Global Mobile Market Report, while 40.010.000 smartphone users were found in 2017 in our country, this figure reached 44.771 .000 in 2018 (Newzoo, Glabal Mobile Market Report, 2018). Based on the information gained, consumers of 44,771,000 using Apple, Samsung, LG, General Mobile, Lenovo, Asus, Casper, Venus, Nokia, Sony, Huawei, HTC and other operator smartphone brands are creating the target universe of research. Based on the data obtained by Düzce Provincial Population Directorate in January 2018, there are 377,610 people making up the provincial population. Consumers who reside in the province of Düzce over 17 years of age and who use any of these smartphones constitute the working universe of research. Since it is impossible and costly to reach the whole of the research universe and the time of the research is limited, a sample selection process has been carried out which constitutes a limited part of the universe. It was determined that the sample of 385 smartphone users reached in the research could represent the universe. For sample selection was used convenience sampling method from non-probability sampling techniques in accordance with research purpose. The number of sample determined by the online questionnaire system was tried to be reached in the research. The scales used in the questionnaire were taken from the following researchers; brand image and customer satisfaction (Quoquab, Basiruddin and Rasid, 2014, s. 214), customer loyalty (Kalyoncuoğlu and Faiz, 2017a, s. 196). The research data was obtained from 385 smartphone users through the online survey between the dates of 3 April 2018 and 22 April 2018. Gathered data were analyzed using SPSS 18.0 packet programs.

\section{Findings}

As a result of research participants form $68.3 \%$ women, the remaining $31.7 \%$ male participants. Participants use 41\% Apple, \%30,1 Samsung and the remaining $29,9 \%$ other smartphone brands. In the analysis of the research data, firstly Explanatory Factor Analysis (AFA) was separately applied to the data related to brand image, customer satisfaction and customer loyalty. According to this result, the variables subject to the research brand image, customer satisfaction and customer loyalty were collected under a single dimension.

As a result of the AFA, a correlation analysis was conducted to determine the relation between variables collected under one dimension. As a result of the correlation analysis, the highest level significant and positive relationship has emerged between customer satisfaction and customer loyalty. $(, 835)$, later respectively, the significant and positive relationship has emerged between brand image and customer loyalty $(, 674)$ and finally, the significant and positive relationship has emerged between brand image and customer satisfaction $(, 647)$.

Within the scope of the research, four-step The Causal Inference Approach of Baron and Kenny (1986) was used to determine the mediating role of customer satisfaction in the effect of brand image on customer loyalty. Regression analysis was conducted to test Baron and Kenny's four-step method and research hypotheses. As a result of the regression analysis, 
Figure 1: The Mediating Role of Customer Satisfaction in the Impact of Brand İmage on Customer Loyalty in the Smartphone Market

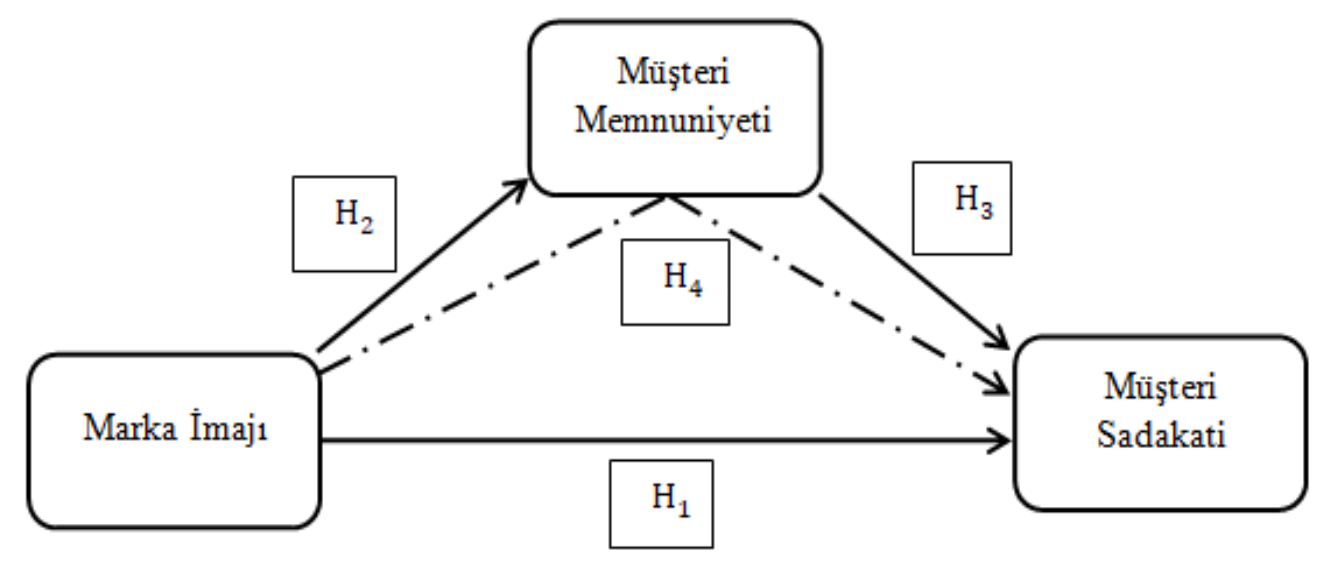

Step 1 (Figure: $1 ; H_{1}$ ), brand image has been determined to have a positive and significant effect on customer loyalty $\left(R^{2}=0,454, \beta=0,674, \mathrm{p}<0,01\right)$ and $H_{1}$ supported, Step 2 (Figure: 1; $H_{2}$ ), brand image has been determined to have a positive and significant effect on customer satisfaction $\left(R^{2}=0,418, \beta=0,647, \mathrm{p}<0,01\right)$ and $H_{2}$ supported, Step 3 (Figure: $1 ; H_{3}$ ), customer satisfaction has been determined to have a positive and significant effect on customer loyalty $\left(R^{2}=0,697, \beta=0,835, \mathrm{p}<0,01\right)$ and $H_{3}$ supported. Compared to Step 1 and Step 4, In Step 1 the effect of the brand image variable on customer loyalty was $\beta=0.674, \mathrm{t}=17.852, \mathrm{p}<0.01$ while, In Step 4 , this effect appears to decrease to $\beta=0.230, \mathrm{t}=6.578, \mathrm{p}<0.01$. According to this finding, customer satisfaction assumes the role of "partial mediating" between brand image and customer loyalty. After all conditions are met, the Sobel Test was used to check the statistical significance of the mediating model in the last stage (Kalyoncuoğlu, 2017, s. 394; Gürbüz and Şahin, 2017, s. 288). As a result of the calculation of the Sobel Test, it was determined that the mediating effect was statistically significant $(\mathrm{z}=14.570, \mathrm{p}$ $<0.01$ ). According to this finding, the effect of the brand image on customer loyalty is that the customer satisfaction is a "partial mediating" variable and $H_{4}$ supported. (Figure: $1 ; H_{4}$ )

\section{Conclusion}

As a result of this research, in the smartphone sector, it has been found that brand image is influential on customer loyalty and customer satisfaction, at the same time, customer satisfaction is influential on customer loyalty. In the smart phone market, customer satisfaction has been achieved as the partial mediating role of brand image over customer loyalty. In other words, consumers who use smartphones are increasing their satisfaction levels thanks to the brand image they perceive as strong, high quality and innovative. Increased customer satisfaction enhances customer loyalty positively. As another consequence of the intermediation of customer satisfaction, thirteen smartphone brands that are the subject of the research, even if negativities in brand 
image in the competitive environment, consumers who are satisfied with the business, continues to prefer this business. At this point, customer satisfaction is a bridge between brand image and customer loyalty. As a result, the image of the smartphone brands on the market is perceived as strong by the consumers and customers who are satisfied with these smartphone brands are becoming loyal to business. 